\title{
RULE OF LAW - EU'S COMMON CONSTITUTIONAL "DENOMINATOR" AND A CRUCIAL MEMBERSHIP CONDITION ON THE CHANGED AND EVOLUTIONARY ROLE OF THE RULE OF LAW VALUE IN THE EU CONTEXT
}

\author{
Marija Vlajković, LLM, Teaching and Research Assistant \\ Faculty of Law, University of Belgrade, \\ Department for International Law and International Relations, \\ Bulevar Kralja Aleksandra 67, Belgrade, marija.vlajkovic@ius.bg.ac.rs
}

\begin{abstract}
For decades the Rule of Law has been emphasized as a core constitutional value common to all Member States of the European Union, although its substantial content was not precisely determined enough in the European context. Moreover it was defined as a multilayered value that encompasses other values such as democracy and fundamental rights, and it was underlined as one of the most important conditionality criteria for the EU enlargement policy. The ongoing crises of EU values, and more precisely the Rule of Law crisis, appeared long before, but reemerged fiercely with the creation of the "illiberal state" concept in Hungary and then in Poland. The EU has implicitly and more successfully, through the work of its institutions tried to compensate for the inadequate and a "a little too late" reaction, as well as for the lack of monitoring in the previous enlargement circles.

The aim of this article is to show how, the rule of Law was stressed as a leading value shaping democratic constitutions and national, as well as supranational, legal systems. It is important to demonstrate that the Rule of Law is not only "coined" for the EU or Council of Europe purposes, but that it is firstly a value that is in the core of each constitutional tradition of a sovereign state. Therefore, in order to be promoted as common and set as a strong and rigid condition for future members, it should be, pro futuro, analyzed, understood and endorsed by EU institutions on each level. Finally, we take Western Balkan countries as an example where the Rule of Law is defined as a value but also as a core basis of the Negotiation Chapters 23 and 24, determined in a more thorough and precise way than in the EU and among its Member States, where, we could agree, it should have been in the first place. We point out to the need of getting closer to its uniform understanding in and outside of the EU and therefore to the need to create a continuous and stable Rule of Law concept both substantially and formally.
\end{abstract}

Keywords: Rule of Law, Values, Treaty on the European Union, Court of Justice of the EU, European Commission, Rule of Law Framework, Conditionality, Western Balkans 


\section{INTRODUCTION}

We are decades away from the image of the European Unionas a Community with the sole purpose of establishing and effectively running the Single market. The "Community to Union evolution" had a political impact so strong, it was obvious that principles, or later on, values, such as democracy, human rights and the rule of law will become more than mere "side-effects of the EU free-movement mission". ${ }^{1}$ And so they did.

With the Treaty of Maastricht, ${ }^{2}$ the newly established European Union faced challenges that went well beyond the economic development and cooperation: preparing for the future enlargements that would more than double its size and capacities, the European Council established Copenhagen Criteria ${ }^{3}$ that envisaged not only economic but also political criteria. Not long after, the EUprovided an EU primary law basis for the common principles in the Treaty of Amsterdam. ${ }^{4}$ This was the first time that the principles, which the EU proclaimed to be founded on, were formally confirmed, so any other state that aspires to become a Member should also adhere to. In addition, at the same time the EU, in preparing for the future enlargements, introduced a sanction mechanism in the case that Member States did not respect the aforementioned principles. Further on, in the Article 2 of the Lisbon Treaty, the principles became "valuescommon to all Member States", even though it was never explained, why the Union accepted the expression "common values" instead principles, and whether (and to what extent) the difference was only lexical.

"United in Diversity" motto, coined two decades ago, proved to bring more than just a symbolically enlarged political Union of 28 (now 27) states. One of the values, that underpins all other values, the rule of law, faced backsliding in not one, but several Member States that, at the time of their entrance,fulfilled the Copenhagen Criteria and respected Article 49 of the Treaty. Even though the rule of law was at first symbolically introduced, the importance of this principle grew to bein the centre of legal and political disputes on the national as well on supranational level. The lack of its respect in Austria, then in France, Romania and afterwards

Herlin-Karnell, E., The EU as a Promoter of Values and the European Global Project, German Law Journal. no. 13, 2012, p. 1227

TEU (Maastricht)

Copenhagen European Council, Presidency Conclusions [1993] SN 180/1/93 REV 1

Article F (1) TEU (Amsterdam)

Article 2 (1), TEU (Lisbon): "The Union is founded on the values of respect for human dignity, freedom, democracy, equality, the rule of law and respect for human rights, including the rights of persons belonging to minorities. These values are common to the Member States in a society in which pluralism, non-discrimination, tolerance, justice, solidarity and equality between women and men prevail." 
in Hungarydid not suffice to activate the so-called "nuclear option" ${ }^{\text {, }}$ but it was against Poland in December 2017that the EU finally triggered the infamous Article 7.

The recent events caused a stir and the rule of law backsliding ${ }^{7}$ resulted not only overtly in Article 7 activation but also in numerous cases that ended before Court of Justice of the European Union against again Hungary and Poland. The rule of law, which now features prominently in the EU primary law, ${ }^{8}$ is not only proclaimed as a common value of its Member States but also as anobjective that Union must pursue, ${ }^{9}$ as well as the condition for the future EU candidates. Therefore, the rule of law, as a value, underlines the whole idea of European integration and is confirmed to be a political and legal conditio sine qua non criterion to enter the European Union.

In this article we will try to understand the lack of uniform definition of the EU rule of law as a meta-value of the European Unionthrough initial judicial activism and through the EU Institutions' documents. We believe that the emergence of the rule of law crisis and the Copenhagen dilemma ${ }^{10}$ stem precisely from the lack of understanding of the this value as well as widely and loosely perceivedconditionality criteria from both sides at the negotiation table. This is very visible now in the presence of the so-called illiberal states. ${ }^{11}$ In relation to this "painfully present" issue, wewill also put a special emphasis on the rule of law enforcement instruments prepared by the EU institutions as a response. Finally, in order to shed a light on the seriousness of this issue in the EU, but also in relation to the candidate countries, Western Balkans' negotiation process will be analysed through the rule of law prism and the prospective proposed New Methodology.

6 José Manuel Durão Barroso President of the European Commission State of the Union 2012 Address Plenary session of the European Parliament/Strasbourg 12 September 2012, [https://ec.europa.eu/ commission/presscorner/detail/en/SPEECH_12_596], accessed 20. March 2020

7 Kochenov D.; Pech, L., Better Late than Never? On the European Commission's Rule of Law Framework and its First Activation, Journal of Common Market Studies, str.Nonih pitanja koje je proiziof Law, marijastr.Nonih pitanja koje je proiziof Law, marijano. 5, 2016, p. 1063

8 Sadurski, W., Adding Bite to a Bark: The Story of Article 7, EU Enlargement, and Jorg Haider, Colum. J. Eur. Law, no. 16, 2010, p. 386

9 Article 3 (1) TEU (Lisbon)

10 Speech: Safeguarding the rule of law and solving the "Copenhagen dilemma": Towards a new EU-mechanism, [https://ec.europa.eu/commission/presscorner/detail/da/SPEECH_13_348], accessed 18. March 2020

11 Or as the Hungarian Prime Minister Viktor Orban tends to call it "illiberal democracy": [http:// abouthungary.hu/blog/pm-orban-at-tusvanyos-the-essence-of-illiberal-democracy-is-the-protection-of-christian-liberty/], accessed 13. January 2020 


\section{IN SEARCH OF THE DEFINITION - "MULTI-LAYERDNESS"12 OF THE EU RULE OF LAW AND THECOURT OF JUSTICE TO THE RESCUE?}

It is very common to "dissect" the concept (or the lack of it) of the EU rule of law by stating that the Treaties' articles introduced common values in order to symbolically present the legal and political union with the aim of buildingthe European identity. This is not far from the truth, if we look at the 1973 Declaration on the European identity ${ }^{13}$ and the Treaty establishing the Constitution on Europe ${ }^{14}$ of which majority of provisions were left unaltered in the Treaty of Lisbon. A homogeneity clause, ${ }^{15}$ as the Article $2 \mathrm{TEU}$ is perceived, was so vaguely determined, in order to regulate EU values understanding on both horizontal and vertical level. It was meant to bring together two main ideas- constitutional homogeneity or the minimum of it, as well as constitutional diversity and pluralism in a very specific political and legal system. ${ }^{16}$ This was especially visible after the2004 "Big-Bang enlargement" where two parallel processes occurred: introduction of common values and the establishment of Copenhagen Criteria, which were, evidently, determined by 12 then existing Member States. ${ }^{17}$ Not more than a decade after, 15 more states became members, and despite their shared experiences, geopolitical position and declared shared common values, they had, and still have, profound social, political differences and substantial discrepancies that it was almost impossible to claim that there ever was a common, or even uniform understanding of values.

The rule of law, as Brian Tamanaha claims was, and is, the one point on which there was a widespread agreement since the beginning: that it is "good for everyone". ${ }^{18} \mathrm{It}$ became a leading value, either encompassing other values such as democracy and

12 Vlajkovic, M.; Tasev, J., The Lack of Uniform Understanding of the Rule of Law in the EU and its Implications on Prospective Member States, Transition of Legal Systems 30 Years after the Fall of the Berlin Wall, Law Review Iustinianus Primus Special Issue - Conference Proceedings, Skopje, North Macedonia, 8-9 November 2019

13 Declaration on European Identity", Bulletin of the European Communities, Luxembourg: Office for official publications of the European Communities, No. 12, December 1973

14 Treaty establishing a Constitution for Europe, [https://europa.eu/european-union/sites/europaeu/ files/docs/body/treaty_establishing_a_constitution_for_europe_en.pdf], accessed 20. February 2020

15 Delledone, G., Homogeneity and Constitutional Diversity in the EU : Protecting Fundamental Rights and the Rule of Law, [https://dial.uclouvain.be/pr/boreal/object/boreal:178155], accessed 22. February 2020

16 Lukić, M., Pluralizam ustava ili ustavnih činilaca? Konstitucionalizacija prava Evropske unije, Teme, no. 4, 2013, pp. 1705-1718

17 Copenhagen European Council, Presidency Conclusions [1993] SN 180/1/93 REV 1

18 Tamanaha, B., On the Rule of Law: History, Politics, Theory, Cambridge University Press, 2014, p.1 
fundamental rights or making a "holy trinity of values" ${ }^{19}$ together with them. In the European discourse it was the "it" value, the value that was referred the most, from Walter Hallstein's speeches in the 1960s and his endorsement of the "community of law founded on the rule of law principle", ${ }^{20}$ to first judiciary acclamation in the opinion of the Advocate General Mancini in one of the most famous judgements Les Verts v Council. ${ }^{21}$ However, as an argument, and maybe a basis for the noticeable lack of uniform understanding of the rule of law notion, we should quote Professor Joseph Weiler: "the rule of law is not in the EU's DNA"22. It is a principle that was coined for the purposes of finding the constitutional common ground for all Member States that are part of sui generis entity and it was suppose to be a "theoretical principle rather difficult to construe". ${ }^{23}$ This means that the rule of law is not only lexically diverse, having in mind 27 Member States, but also substantially as Rechstaat and L'état de droit are not, in their own constitutional systems, understood and perceived in the identical sense.Even when we talk about the most used notion- the (English) rule of law, we should mention that in 2006 and 2007 the House of Lords Select Committee on the Constitution engaged Professor Paul Craig to, among other things, try to give a precise understanding of the rule of law meaning which resulted with a conclusion that, despite the hard work on the analysis, the "rule of law is and remains a complex and in some respects uncertain concept". ${ }^{24}$ Moreover, the dual role of the rule of law in the EU integration made the concept even more complex: on the one side, its role was to strengthen the legal and political foundation of the Union and its Member States within, and on the other side its role was moreof a "missionary"-in the function of the Common Foreign Policy with special emphasis on the enlargement. ${ }^{25}$ Uncertain in its nature and content, the EU rule of law was not even defined in its theoretical

19 Kochenov, D., The Acquis and Its Principles, in: A. Jakab, D.; Kochenov, D. (eds.), The Enforcement of EU Law and Values: Ensuring Member States' Compliance, Oxford University Press, 2017

20 The EU as a community of law: Overview of the role of law in the Union, [https://www.europarl.europa. eu/thinktank/fr/document.html?reference=EPRS_BRI\%282017\%295993641, accessed 10. March 2020

21 Case C/294/83, Partiécologiste "Les Verts" v. European Parliament [1986] ECR 1986 -01339, par. 23

22 Kochenov D., The EU and the Rule of Law - Naïveté or a Grand Design?, in: Adams, M. et al. (eds.) Constitutionalism and the Rule of Law: Bridging Idealism and Realism, Cambridge, 2017, p. 427

23 Baratta, R., Ruleof Law 'Dialogues' Within the EU: A Legal Assessment, Hague Journal on the Rule of Law, no. 2, 2016, p. 358

24 House of Lords Select Committee on the Constitution, Relations between the executive, the judiciary and the Parliament, HL Paper 152, 2006-2007, p. 12

25 Articles 8 and 49 TEU (Lisbon) 
sense: was it thick or thin, ${ }^{26}$ or somewhere in between coined for specific purposes, whether internal or external?

Throughout the years, more specifically until 2014 Commission's Framework ${ }^{27}$, the only EU institution that seemed to be either referring to the rule of law in the context of the EU, while at the same time giving telle-quelle reference relevant for the rule of law substance, was the Court of Justice of the EU (CJEU). It is important to remind that the rule of law, in the sense of Article 2 TEU is not part of the EU aquis stricto sensu, ${ }^{28}$ and therefore the Court cannot rule solely on the basis of the non-respect of the values that are stated in the Article 2. An enforcement of values was expected to be resolved throughout a more political procedure envisaged in the Article 7, and the Courtdoes not have jurisdiction over theArticle 7 activation, except for the procedural reasons. However, the Court has brought to (legal) life the values especially the rule of law, starting from the interpretation given in 1986 in the aforementioned Case Les Vertsv Parliament ${ }^{29}$ where it referred for the first time very explicitly to the rule of law role in the Community. Further on, in the CaseCommission v. EIB $^{30}$ the rule of law was also mentioned by the Court, but understood purely inprocedural/judicial terms, ${ }^{31}$ whereas in the Case UPA v

26 One of the formal, thin definitions is given and explained by Tamanaha: "The rule of law, at its core, requires that government officials and citizens are bound by and act consistent with the law. This basic requirement entails a set of minimal characteristics: law must be set forth in advance (be prospective), be made public, be general, be clear, be stable and certain, and be applied to everyone according to its terms.", Tamanaha Brian, A concise guide to the Rule of Law, The Social Science Research Network Electronic Paper Collection, Paper 07-0082, 2007. Par rapport "in a thick, or 'democratic rule of law', conception laws enshrine and protect political and civil liberties as well as procedural guarantees", Magen A., Cracks in the Foundations: Understanding the Great Rule of Law Debate in the EU, JCMS 2016 vol. 54. no. 5, p. 1053

27 Communication from the Commission (COM) 2014/0158 to the European Parliament and the Council a new EU Framework to strengthen the Rule of Law, 2014

28 Sadurski, op.cit., note 8, p. 1063

29 See note 21, par. 23: "It must first be emphasized in this regard that the European Economic Community is a Community based on the rule of law, inasmuch as neither its Member States nor its institutions can avoid a review of the question whether the measures adopted by them are in conformity with the basic constitutional charter, the Treaty"

30 Case C-15/00 Commission v. BEI [2003], ECR I-7281 par. 75: "Such an interpretation would also ignore the fact that the European Community is based on the rule of law, inasmuch as neither its Member States nor its institutions can avoid a review of the question whether the measures adopted by them are in conformity with the basic constitutional charter, the EC Treaty, which established a complete system of legal remedies and procedures designed to permit the Court of Justice to review the legality of measures adopted by the institutions"

31 Pech, L., A Union Founded on the Rule of Law: Meaning and Reality of the Rule of Law as a Constitutional Principle of EU Law, EU. Const, no. 6, 2010, p.372 
Council $^{32}$ and later on in Case Kadi v Council and the European Commission, ${ }^{33}$ the Court showed progressive tendency towards the more substantive understanding of the rule of law leaning towards the thick concept. This was also in the Case PKK v. Council case where the Court reiterated that the Community is based on rule of law "in which its institutions are subject to judicial review of the compatibility of their acts with the EC Treaty and with the general principles of law which include fundamental rights". ${ }^{34}$ Moving towards the deeper understanding of the EU rule of law could also be regarded as a judicial perspective of a political Union with stronger constitutional basis in the material sense. ${ }^{35}$ The rule of law seemed to represent, at least for the Court, an umbrella-principle ${ }^{36}$ that will encompass other values and should underpin the constitutional character of the EU. Judicial activism in the rule of law sphere reached its peak in 2014, right about the same time as the values crises started to "boil". In the Case Associagao Sindical dos Juizes Portugueses (ASJP) (request for preliminary reference), the Court, while defining Article 19, paragraph 1, second subparagraph $\mathrm{TEU}^{37}$ purposely widened the scope of its application. It made clear that judicial independence, which is without a doubt a crucial element of the rule of law, stretches to all national jurisdictions which might in general be confronted with questions relating to the application of Union law. ${ }^{38}$ It enhanced the enforceability of the rule of law standards vis-à-vis the EU Member States ${ }^{39}$ and even though it leanedagain towards the thin concept of the EU rule of law, the Court pointed out that the enforcement of the rule of

32 Case C-50/00, Unión de Pequeńos Agricultores v Council of the European Union [2002], ECR I667, par. 38-39

33 Joined Cases C-402/05 P and C-415/05, Yassin Abdullah Kadi and Al Barakaat International Foundation v Council of the European Union and Commission of the European Communities [2008] ECR I-6351

34 Case C-229/05 P, Osman Ocalan, on behalf of the Kurdistan Workers' Party (PKK) and Serif Vanly, on behalf of the Kurdistan National Congress (KNK) v Council of the European Union, ECR [2007] i-349, par. 109

35 Note that in almost every judgment mentioned above, the constitutional importance of the Treaties is underlined. See for example Les Verts par. 75 or Kadi par. 81 and par 281. For an earlier reference see Opinion 1/91, European Court Reports 1991 I-06079, par. 21: "In contrast, the EEC Treaty, albeit concluded in the form of an international agreement, none the less constitutes the constitutional charter of a Community based on the rule of law"

36 Pech, op.cit., note 31, p. 369

37 Article 19 (1 (1)) TEU (Lisbon): "Member States shall provide remedies sufficient to ensure effective legal protection in the fields covered by Union law."

38 Case C-64/16, Associação Sindical dos Juízes Portugueses v Tribunal de Contas, Request for a preliminary ruling from the Supremo Tribunal Administrativo, ECLI:EU:C:2018:117, par. 39

39 Krajewski, M., Associação Sindical dos Juizes Portugueses: The Court of Justice and Athena's Dilemma, [http:// www.europeanpapers.eu/en/europeanforum/associacao-sindical-dos-juizes-portugueses-court-of-justice-and-athena-dilemma], accessed 15. March 2020 
standards (read: effective judicial protection) should be more straightforward..$^{40}$ Moreover, this judgment elaborated all CJEU case-law relevant for the development of the rule of law understanding in the EU context. In addition it combined the Article 2 TEU, Article 4 (3) TEU that proclaims principle of sincere cooperation and finally Article 19(1) TEU, which the Court read and interpreted in the sense of the first two articles. This was the Court's answer to the acceleration of the rule of law backsliding without a proper EU response in sight. However, even though the development of the rule of law reasoning and the filling the lacunae in the EU rule of law substance by the CJEU was more than welcome, it was far from a satisfactory answer for the deeply rooted rule of law crisis where no enforcement was provided on the EU level grosso modo.

\section{THE AFTERMATH OF THE CONDITIONALITY CRITERIA - WHAT NOW?}

\section{1. "Mistakes" from the past: from conditionality to crisis}

The pre-accession conditionality that marked the EU enlargementscould be seen as divided into acquis conditionality and quasi-acquis or democratic conditionality. Having in mind the specificity of the latter -the fact that the Union does not have the right to legislate in those field $s^{41}$, made it very hard to form an uniform EU conditionality policy, introduced by the Commission, with a view on democracy, rule of law and other values. Moreover, since the eastern enlargement was considered to be one of the most successful EU foreign policy moves, this type of political conditionality was copy/pasted into the subsequent enlargements. Thereforethe lack of clear and strict standards on how to evaluate and determine the existence of the rule of law and other values respect was replicated in new and repacked enlargement policies. It is also common opinion that the Commission, as a "technical" leader of the negotiations, had the opportunity to add the substance to the non-transparent and vagueconditionality criteria. However, it failed to do so, leaving the negotiations requirements on the good old bureaucratic measures and sometimes subjective estimations. These drawbacks went on for a decade and resulted in the ongoing crisis.

To prove and connect the "pre-accession conditionality with post-accession conundrums" ${ }^{\prime 2}$, especially when it comes to the implementation, protection and

\footnotetext{
$40 \quad$ ibid.

$41 \quad$ Article 4 (1) TEU (Lisbon)

42 Hillion, C., EU Enlargement, in: Craig, P.; Graine de, B. (eds.), The Evolution of EU law, Oxford University Press, 2011
} 
respect of the rule of law, we should firstly point out to the transformative power of the EU conditionality policy tool- the promise of membership. Conditionality, that is the most effective enlargement instrument, suggests that after fulfilling conditions, there should be a strong assumption of the functioning democracy and shared values among all Member States, the old and the new ones. Taking into consideration that, starting from the 2004 enlargements, all candidate countries were at the same time going through a transformative process and politicojudicial transition, in parallel with the EU negotiation process, their choice to have their own understanding of the rule of law was replaced by the technique of "mirroring". According to some authors, ${ }^{43}$ in order to successfully cross-out all the requirements on their way to the EU, Central and Eastern European countries accepted the principles that were common to the states that were already in the EU, and that they perceived as ideal values of the West. This understanding was also facilitated by the lack of clarity as the values such as democracy, rule of law and protection of fundamental rights were intertwined in their conceptual understanding, sometimes encompassed by the rule of law in toto. The Copenhagen dilemma was actually depicted in the following problematic: firstly, the EU begins and ends membership negotiations without taking into account conceptual and constitutional variations of the rule of law and values in general; ${ }^{44}$ secondly in order to fulfil the imposed criteria of the rule of law respect, the candidate countries formally adhere to the EU common values standard without precise assessment; and finally, as the result of the previous two, with every new circle of enlargement a discrepancy between the respect of the rule of law as a pre-membership condition and post-accession respect and promotion by the new Member States is more and more visible. The issue of double standards should be mentioned as it concerns legal obligations set out in Article 3 TEU par rapportArticle 49 TEU. Respect, as well as the promotion of the rule of law value, is an eligibility criterion for the application for membership, and later ona requirement throughout the whole negotiation process for the membership itself. When it comes to Member States in their post-accession status, Article 3 TEU sets an aim for the EU to promote, among other things, the values of the EU. So, on the one hand we have a stronger legal obligation- requirement to respect and promote values whilst a candidate, but on the other, once a Member State, the legal obligation "loosens up". One may say that in connection with the principle of sincere cooperation and mutual trust, and together with Article 7 mechanism, the assumption that Member States shall remain functioning democracies with inherent protection of the rule of law

\footnotetext{
43 For more see: Claes, M., How Common are the Values of the European Union?, Croatian Yearbook of European Law and Policy, no. 1, 2019 as well as Torcol,S., Partager des valeurs communes, préalable à l'émergence d'un droit constitutionneleuropéen, Revue de l'Union européenne, 2017

44 Mineshima, D., The Rule of Law and EU Expansion, Liverpool Law Review, no. 1-2, pp. 73-74
} 
and fundamental rights is totally justifiable. Nevertheless, if the values were only formally respected ${ }^{45}$ upon entering, without shared understanding or profound respect, can we expect that declarative sentencesset out in the Treaty's Common provisions, should secure the above mentioned goal in continuum?

A copy/paste method used in conditionality policy proved to be very efficient when it comes to the formal fulfilment of conditions and respect of membership requirements on the superficial level in order to fit in, but not to adapt the existing. This resulted in a general acclamation of the rule of law respect, but the way this concept was utilised and made a part of the newly transformed governing system and structures, greatly differed. ${ }^{46}$

\subsection{Is there a Common answer to the Common values crises?}

The CJEU, continued to make significant, yet indirect steps, towards Article 2 protection, with focus on the coreelements of the rule of law protection. Interpretation of the Article 19 TEU in conjunction with Article 2 TEU in the ASJP judgement ${ }^{47}$ shed a new light to the rule of law protection and had far-reaching judicial consequences, as seen in the cases that were brought before the Court against Hungary and moreover against Poland. ${ }^{48}$ In November 2019, in joined Polish cases, the Court applied "the fine tuning of Article 2 with Article 19", ${ }^{49}$ and made a greater impact than mechanisms provided by the EU institutions or even Article 7 TEU. The Court did not miss the chance to underline what rights constitute the legalunderstanding of the Article 2 and in particular the rule of law. ${ }^{50}$ In that respect, it was clear that the Court's judicial reaction, although restricted in accordance with the action for failure to fulfil obligations under Article 258 TFEU, was perceived as a double response: on the one side it provided a counterbalance to the

45 Formally, in this context, refers to the fact that the respect of the values and the rule of law per se is fulfilled only to a certain extent, to satisfy the conditionality criteria, and in that sense, it could be similar to the abovementioned thin concept of the rule of law

46 Pishev, O., Dilemmas of the Transition Period, Problems of Communism, no.1-2, 1992, p. 83

47 Case C-64/16, Associação Sindical dos Juízes Portugueses v Tribunal de Contas

48 Joined Cases C-585/18, C-624/18 and C-625/18 A.K. v Krajowa Rada Sądownictwa, and CP and DO v Sąd Najwyższy [2020] OJ C 27/6. Also see CJEU judgment: Case C-619/18 Commission v Poland (Independence of Supreme Court), ECLI:EU:C:2018:910

49 Kochenov, D., Elephants in the Room: The European Commission's 2019 Communication on the Rule of Law, Hague Journal on the Rule of Law, no. 11, 2019, p. 427

50 "The Court points out that the fact that the independence of the SądNajwyższy may not be guaranteed is likely to cause serious damage to the EU legal order and thus to the rights which individuals derive from EU law and to the values, set out in Article 2 TEU, 8 on which the EU is founded, in particular the rule of law", Court of Justice of the European Union, Press Release No 47/20, [https://curia.europa.eu/jcms/upload/docs/application/pdf/2020-04/cp200047en.pdf], accessed 10. April 2020 
EU institutional inactivity and on the other to the Member States' national courts' disregard of the rule of law protection. However, the question remained where to draw the (very) fine line between supranational competence and national jurisdiction, especially when it comes to values which are outside of the EU competences but part of the EU foundation? In providing the reasoning for this Court's activism in the recent judgments, Koen Lenaerts, the President of the CJEU, explained that the European integration is possible only through the rule of law depicted in judicial independence and effective judicial protection principles that are indeed supranational and circumscribe national principles. He goes on to explain that the "Court of Justice does not seek to redesign national judiciaries" 51 but it limits itself in examining if national courts and national rules are in accordance with the aforementioned principle. The Europeanisation through the Court's work is not without its own shortcomings. It could and should provide red lines, although indirectly, for the rule of law infringements, as Armin von Bogdandy et al. stated when commenting the Case Minister for Justice and Equality v LM. ${ }^{52}$ However, the role of the Court is not to be a substitute for the European institutions and their lack of efficient response in deepening the European integration through the rule of law respect and protection.

On the institutional side, Commission's Rule of Law Framework ${ }^{53}$ had considerably contributed, however not as efficient instrument, even though it was its principal purpose. Namely,it added even more steps prior the Article 7 activation and questionably broadened the Commission's competences and discretionary power, questioned by the EU Council..$^{54}$ However, it brought, for the first time, a solid definition of the rule of law components in the EU legal system and its importance as an EU value. ${ }^{55}$ As it was said, the Council was not in accordance with

51 Lenaerts, K., New Horizons for the Rule of Law within the EU, German Law Journal, vol. 21, 2020, pp. 29-34

52 Von Bogdandy, A. et al., A potential constitutional moment for the European rule of Law - The importance of red lines, Guest Editorial, Common Market Law Review, vol. 55, pp. 983-996; Case C-216/18 PPU Minister for Justice and Equality v LM, Judgment of the Court (Grand Chamber) of 25 July 2018 ECLI:EU:C:2018:586

53 Communication from the Commission (COM) 2014/0158 to the European Parliament and the Council a new EU Framework to strengthen the Rule of Law, 2014

54 As it was said in the Press Release, following the Council of the European Union, General Affairs Opinion, the Council proposed another mechanism in order to ensure an effective respect the rule of law: "The Council held an exchange of views on an idea to establish a regular political dialogue among member states within the Council on ensuring respect for the rule of law", [https://www.consilium. europa.eu/uedocs/cms_data/docs/pressdata/EN/genaff/145844.pdf], accessed 27. February 2020

55 An overview of the relevant case law on the rule of law and the principles which the rule of law entails was set in the Annex I to the Framework. In addition, in a subsequent Commission's document from 2019 a definition is given on page 2 in order to answer the question: "What is the rule of law?", Communication from the Commission to the European Parliament, the European Council and the 
Commission's Framework proposed mechanisms. It proposed a different solution that envisaged more of a "dialogue among peers" instead of EU-driven process. ${ }^{56}$ Moreover, the activation of the Article 7 (1) TEU against Poland, seemed long overdue, since it was actually the first time it was activated since its introduction in the Amsterdam treaty. The above initiatives share common traits: they are deeply political and very slow in activation. A mix of legal and political approaches from different sides, as well as very fragmented response weakens the protection of the rule of law and it causes even more confusion, to the protection concept not only on the EU level, but among Member States as well. ${ }^{57}$ The enforcement of the values, where judicial activation is only possible in indirect manner and where institutional response is defined as "better late than never", ${ }^{58}$ new solutions should definitely be not only considered but rapidly adopted.

The timid reaction by the EU waspublicly criticised, and under the pressure, the Commission proposed a Regulation that would protect the EU's budget in case of the rule of law deficiencies in Member States. The Proposal introduces sort of a rule of law conditionality policy in order to protectthe Union's budget by introducing measures that would be directed towards one or several Member States as regards to the non-respect of the rule of law. ${ }^{59}$ It also provides with two definitions among which the first one determines the rule of law as a Union value and its legal components. ${ }^{60}$ While awaiting the legal outcome of this Proposal, we should stress the characteristics and possible impact of this document. This Document underlines, as the 2014 Commission Framework already did, that the rule of law backsliding is definitely not a purely internal issue. By connecting financial resources with the issue of the rule of law protection, the EU Commission used a tested tool used in the EU external policy, especially in enlargement and neighbourhood con-

Council Further strengthening the Rule of Law within the Union State of play and possible next steps, [https://ec.europa.eu/info/sites/info/files/rule_of_law_communication_en.pdf], accessed 29. May 2020

56 Kochenov; Pech,op. cit., note 7, p. 624

57 Argyropoulou, V., Enforcing the Rule of Law in the European Union, Quo Vadis EU?, [https://harvardhrj. com/2019/11/enforcing-the-rule-of-law-in-the-european-union-quo-vadis-eu/\#_ftn1], accessed 28. February 2020

58 Kochenov; Pech, op. cit., note 7

59 Commission Proposal for a Regulation of the European Parliament and of the Council on the protection of the Union's budget in case of generalised deficiencies as regards the rule of law in the Member States, COM(2018) 324 final

60 Article 1 (a) Commission Proposal: "the rule of law' refers to the Union value enshrined in Article 2 of the Treaty on European Union which includes the principles of legality, implying a transparent, accountable, democratic and pluralistic process for enacting laws; legal certainty; prohibition of arbitrariness of the executive powers; effective judicial protection by independent courts, including of fundamental rights; separation of powers and equality before the law." 
ditionality policy. Even though this "spending conditionality" ${ }^{61}$ mechanism seem as a more powerful instrument vis-a-vis Member States, it would be useful to point out that conditionality per se is not characteristic for the (EU) internal matters, having in mind that upon the entry, the pre-accession conditionality is replaced with mutual solidarity. ${ }^{62}$ The only exception to this case is asthe Cooperation and Verification Mechanism $(\mathrm{CVM})^{63}$ introduced in Bulgaria and Romania, which, regardless of the membership of the aforementioned states, has the conditionality scheme in its core. ${ }^{64}$ In addition, we arrive again to the issue between the supranational mechanism and reserved national legal affairs, with an additional question of theEU Commission's discretionary powers that should be examined. When potentially applying this mechanism, the EU Commission itself may come to a situation to be close to disregarding the principle of conferral and legal certainty, and therefore potentially risking the EU rule of law principle with its own actions. ${ }^{65}$

Another EU Commission's document, a 2019 Communication: Strengthening the rule of law within the Union ${ }^{66}$ was welcomed as a positive effort of the EU par rapport the rule of law enforcement issue. With the aim of upholding the rule of law which is, according to the Communication, a "bedrock of the common identity" ${ }^{67}$, and aside of stressing its own pro-activity, the Commission introduces the regular rule of law reporting cycle and a stronger involvement of Member States in the coordinated and reinforced approach. In addition, as in the Proposal, it paid more attention to the financial conditionality. Moreover it aimed to be far from the EU Commission driven process, by involving not only Member States but engaging civil societies as well as Venice Commission and GRECO of the Council of Europe. This response, besides all others, previously mentioned, seems to be more focused on the promotion than on the reaction or more importantly, efficient and strong response on the EU level. As Dimitry Kochenov rightly

${ }_{61}$ Fisicaro, M., Rule of Law Conditionality in EU Funds: The Value of Money in the Crisis of European Values, European Papers, no. 3, 2019, pp. 701-706

62 ibid., 718

63 Commission, Decision of 13 December 2006 establishing a mechanism for cooperation and verification of progress in Romania to address specific benchmarks in the areas of judicial reform and the fight against corruption, notified under document number C(2006) 6570 final

64 The Commission monitors the fulfillment of benchmarks, which exist in the pre-accession conditionality such as judicial reform including independence of the judiciary, fight against corruption etc. Using this mechanism, the Commission can take appropriate measures that include the suspension of the Member States' obligation to recognise and execute Bulgarian and Romanian judgments

65 Fisicaro, op. cit., note 56

66 Communication from the Commission to the European Parliament, the European Council, the Council, the European Economic and Social Committee and the Committee of the Regions Strengthening the rule of law within the Union, a blueprint for Action, COM/2019/343 final

67 ibid. 
notices, the EU Commission does not explain neither the nature of the rule of law backsliding nor it provides an instrument that will equally match the deeply rooted crisis. ${ }^{68}$

\section{3. "Practice makes perfect" - Western Balkans negotiation process}

When it comes to the Western Balkans' countries, especially Serbia and Montenegro, as they are considered to be the front runners in the negotiation process ${ }^{69}$, the EU Commission's documents seem to determine the rule of law criteria in a more precise and detailed manner than in the previous enlargement rounds. Yearly Progress reports and Chapter specific Screening reports as well as Common positions emphasised the role of the rule of law in the negotiation process. ${ }^{70}$ The significance of the rule of law as a political criterion is especially emphasised in Chapter 23 devoted to Fundamental rights and Judiciary and in a more technical form in Chapter 24 devoted to Justice, Freedom and Security. It is also important to emphasise that those two chapters are, as part of the Commission's altered approach, covered by the separate Non paper and therefore not included anymore in the yearly Progress report with other Chapters covering the acquis. This demonstrates the importance of tackling the two chapters underpinned by the rule of law, separately in a specific document that ultimately dictates the pace of the overall negotiations.

After the sixth circle of enlargement, with the Croatian accession process, the revisedmethodology included opening and closing benchmarks, as well as interim benchmarksand paved the way for further detailed conditionality approach. The shortcomings and lesson learnt from the previous enlargements rounds, were underlined even in the Council Conclusions in 2011, ${ }^{71}$ and the introduced "equal balance clause" or the "imbalance" clause firstly for Montenegro and then Serbia, meant that the success in providing the respect of the rule of law functioning and

68 ibid.

69 Drenovak-Ivanovic, M.; Bogojevic, S., Environmental Protection Through the Prism of Enlargement: Time for Reflection, Common Market Law Review, no 56, 2019, p. 950

70 See for example: Communication From The Commission To The European Parliament, The Council, The European Economic And Social Committee And The Committee Of The Regions 2016 Communication on EU Enlargement Policy, p. 9 [https://ec.europa.eu/neighbourhood-enlargement/sites/ near/files/20161109_strategy_paper_en.pdf], and Commission Staff Working Document Serbia 2019 Report Accompanying the document, Chapter 2, [https://ec.europa.eu/neighbourhood-enlargement/ sites/near/files/20190529-serbia-report.pdf], accessed 29. May 2020

71 Council conclusions on Enlargement and Stabilisation and Association Process 3132nd General Affairs Council meeting Brussels, 5 December 2011, [http://www.consilium.europa.eu/uedocs/cms_ data/docs/pressdata/EN/genaff/], accessed 15. March 2020 
promotion will definitely balance the overall development in all other chapters. ${ }^{72}$ It seemed that this new approach gave, paradoxically, the rule of law value more impact and importance than in the previous enlargement process. It was also motivated by the Croatian experience, as the EU had introduced Chapters underpinned by the respect of the rule law (namely Chapter 23 and 24), however the focus on their substance and respectwas shifted at the end of negotiation process leaving no time to estimate Croatian real fulfilment of the rule of law criteria. ${ }^{73}$

With new challenges arising inside the EU, it was noteworthy to take into account recent documents such as the Commission's Communications in 2016 and subsequently in $2018^{74}$ that again altered the so-far approach and promoted the principle "fundamentals first" that included the rule of law. In a separate chapter in the 2018 Communication, the EU Commission stressed the rule of law principle that should be given the utmost priority, having in mind the momentum in the EU as well. Interestingly enough, driven by the internal EU rule of law issue, the Communication did not miss to stress the need for a more effective mechanisms that will continue to follow the candidate's progress from its beginning throughout the whole process. It seemed that, at least in the recent years, the EU institutions realised that fulfilling the rule of law purely as a formal condition, without the proper understandingwould not suffice as it will come back as a boomerang not only for the country in question but for the EU legal and political system as well. Moreover, the country-by-country experience so far, steered the EU Commission in the right direction towardsstrengthening the prevention instruments in the candidate countries rather than reaction in the EU later on. If we follow the structure of the recent Non paper for Serbia for the Chapter $23,{ }^{75}$ we can see that the rule of law value per se is not mentioned. Nor its definition or understanding in a proper enlargement context is ever specified in an EU institution document. However, is strongly considered, stemming from the whole negotiation narrative and the chapters that fill in the content of the aforementioned benchmarks of the Chapter $23 / 24$ that if the enforcement and development of the functioning judiciary in all its aspects, the anti-corruption measures as well as the protection of fundamental rights show progress, the rule of law is therefore considered respected and equally

72 Pejović, A. A., Vladavin aprava u politici prijema u Evropsku uniju, Matica Crnogorska, no. 66, 2016

73 ibid.

74 Communication from the Commission to the European Parliament, the Council, the European Economic And Social Committee and the Committee Of The Regions 2016 Communication on EU Enlargement Policy, 9.6.2016. COM(2016) 715 finalCommunication from the Commission to the European Parliament, the Council, the European Economic and Social Committee and the Committee of the Regions A Credible Enlargement Perspective for and Enhanced EU Engagement with the Western Balkans, 6.2.2018. COM(2018) 65 final

75 Non-paper on the state of play regarding chapters 23 and 24 for Serbia, November 2019 
protected. In the case of the progress documents related to the Western Balkans, aside of the declaratory statements that accentuate the importance of the respect of the said value, it is assumed that it is to underpin every area of Chapter 23 (and in most parts also Ch. 24) as the Commission once again refers to the external sources such as the Rule of Law Checklist by the Venice Commission. ${ }^{76}$

Regardless of the more specified and focused approach that was updatedin order to prioritise and engage the EU's supervision and involvement, we point out to the following: firstly, as already said, the EU rule of law value and its content are not defined in a single accession document so far; and secondly, aside of claiming that the respect of the rule of law is of utmost priority, ${ }^{77}$ the understanding of what it represents as a common value of the EU, according to article $49 \mathrm{TEU}$ is not given. If we take a look in the Commission's document:A Credible Enlargement Perspective for and Enhanced EU Engagement with the Western Balkans, under the aforementioned rule of law imperative, organised crime, corruption, extensive political interference, lack of independent media as well as independent judiciary and accountable government are listed as issues to be solved. ${ }^{78}$ This is far from the vast Chapter 23 substance, and far from the full or thick rule of law conception. Yet again, we may come to the conclusion that the Commission lacks the substance in demonstrating what exactly is common between the constitutional values such as the rule of law in the candidate countries with the already set values in the EU, even though it repeatedly insists on it. ${ }^{79}$ The common understanding beyond the concept of the rule of law, which varies from thin to thick, on the one side, and its fulfilment by the candidate countries, on the other, is still "in the making". On the one hand, this could be understood, having in mind that the negotiation policy aiming at "fundamentals, such as rule of law, first" is rather new, driven by the prior experiences, still lacking its own proper instruments, as we can see in some areas it heavily relies on the Council of Europe's Venice Commission when it comes to Chapter 23, which is the "heart" of the rule of law application in the accession countries. ${ }^{80}$ On the other hand, however, the only thing that is left for the candidate states is to understand and more importantly fulfil benchmarks

76 Venice Commission, Rule of Law Check-list [https://www.venice.coe.int/webforms/documents/default.aspx?pdffile=CDL-AD(2016)007-e], accessed 17. March 2020

77 Communication, op.cit., note 74, A Credible Enlargement Perspective for and Enhanced EU Engagement with the Western Balkans, pp. 3-4

78 ibid.

79 "The region must embrace these fundamental EU values much more strongly and credibly", Communication, op.cit., note 77, p. 4

80 "Serbia is encouraged to consult the Venice Commission in this legislative reform proces.", Serbia 2019 Report Accompanying the document Communication from the Commission to the European Parliament, the Council, the European Economic and Social Committee and the Committee of the 
of the aforementioned chapters as part of the rule of law negotiation criteria. This also seems rather difficult having in mind that even the EU approach towards accession and its content varies with years.

The New Methodology for the Western Balkans, introduced in February 2020, ${ }^{81}$ obviously responds tothe EU spill-over of the rule of law backsliding. This confirms once again that vague and flawed pre-accession conditionality policy in the previous enlargements was to be altered significantly so the same mistakes are to be avoided pro futuro. The New Methodology re-enforces the Commission's involvement and the monitoring process as well as the Member States systematic involvement. This was also an answer to the EU accession fatigue that re-emerged in the candidate countries, especially when it comes to the prospective EU- membership process. This new approach is not without concerns. Surely, the strong rule of law conditionality will determine the pace of negotiations, and more importantly the opening and closing of the accession negotiations. However, it still does not give a solid definition of what are the EU rule of law components that a candidate country should share, leaving it open to the arbitrariness of both sides. Additionally Serbia and Montenegro, the two states that went the furthest in the negotiations process are to alter the previous for the new methodology, marking the whole process with legal uncertainty. To depict, if for example, the EU rule of law is to be endangered even more in the EU, the EU can again change the accession methodology that is already applied on the candidate countries. Nevertheless, the enforcement and monitoring of the rule of law is indeed an important goal, having in mind the importance of the enlargement process for the internal state of affairs of the EU. Moreover, "fundamentals first" is also the right approach having in mind the experiences of Hungary, Poland, Romania etc. Nevertheless, besides finding the balance between positive and negative incentives while monitoring the negotiation process, the EU Commission should focus also on the substance of the each political and legal reform that has a rule of law rationale behind it. The proper guidance in the New Methodology goals application and understanding its core is of utmost importance for the candidate states and should be on the EU's agenda. Should this be omitted by the EU institutions, namely EU Commission, the Western Balkans' countries could end up with a new set of rules and benchmarks, even more complex to understand and demanding to fulfil without

Regions 2019 Communication on EU Enlargement Policy, p. 16, [https:/ec.europa.eu/neighbourhood-enlargement/sites/near/files/20190529-serbia-report.pdf], accessed 30. May 2020

81 Communication from the Commission to the European Parliament, the Council, the European Economic and Social Committee and the Committee of the regions, Enhancing the accession process - A credible EU perspective for the Western Balkans $\operatorname{COM}(2020) 57$, [https://ec.europa.eu/neighbourhood enlargement/sites/near/files/enlargement-methodology_en.pdf], accessed 22. March 2020 
their clarity. Finally, as a result, the rule of law condition could be perceived by the candidate states as a burden and not a goal and ultimate value in one country.

\section{CONCLUSION}

The EU's handling of the rule of law crisis and the lack of a strong coherent response actually paintsthe real picture of the European identity that aims to be (re)built. This means that even though the idea of the "United in diversity" functioned well as a political motto, it had a little relevance on the practical level. The complexity of finding the proper balance between the unity envisaged through common constitutional values, on the one side andthe expected plurality of constitutions, on the other, is somehow not understood well. The political success of the European enlargement policy seemed to underestimate the importance of the commonunderstanding of the legal and political meaning of each value instead of just proclaiming that a value or a set of values is common. Without taking into account the legal and constitutional specificities of the countries in transition, whether Member States or candidate countries, the European Union chose the "form over substance" approach. The result was nevertheless seen less than a decade after.

With the rule of law backsliding, spilling-over from one EU country to another, it became clear that the rule of law issue is not just formality and purely internal issue. The Court of Justice of the European Union seemed to be the only institution willing to proactively provide the legal basis for the EU rule of law protection. In addition, until 2014 Rule Framework, it was the sole body to touch upon the substance of the EU rule of law, although varying from the thin to thick concept of this value. The EU institutions have failed in two ways: firstly, in achieving a common understanding as to what the rule of law represents in and outside the EU and secondly in enforcing this open-ended value against national authorities. Even when it was past the due time to react the EU Commission, as a response, included procedures that envisaged ex-post involvement and depended on the political will. This could have been avoided if the EU Commission had not been silent about the core problem - the lack of uniform understanding of what the EU rule of law represents. This is without a doubt a highly sensitive business. The reason is not rooted solelyin the somewhat blind acceptance of the Western ideals and values, it was also the strong reliance of both sides that "on paper" all the conditions where fulfilled including the rule of law. This made the understanding the Article 49 TEU as proclaiming "finalité oriented values" 82 where the only goal was

82 Mader, O., Enforcement of EU Values as a Political Endeavour: Constitutional Pluralism and Value Homogeneity in Times of Persistent Challenges to the Rule of Law, Hague Journal on the Rule of Law, 2019, p. 140 
to use the values as an instrument to the Unity, without the substance. The vulnerability of the EU's constitutional structure is rooted exactly between the ideal of the proclaimed values and goals that all States, especially the "new ones" should achieve and the reality that has fragmented integration and lack of coherent EU response. The concern over the application of the rule of law principle instead of trying to define it or find whatrepresents a common constitutional denominator between all the states, is now taking its toll. In near and medium-term future, the EU will need to find, not only a stronger enforcement instruments, whether in spending conditionality or in CVM-like mechanisms, but it would also need to focus on the ex-ante dealing with values. This means dealing with the specificities of the constitutional systems, in accordance with constitutional pluralism and in order to achieve constitutional values homogeneity not only on paper, but in practice.

In order to avoid the same approach, the New Methodology for the Western Balkans should contribute to the stability of the states' adherence to the values that are proclaimed by the EU to be common. Albeit, still without an uniform understanding of the said value, the Union is to tackle general deficiencies in every aspect that the rule of law underpins, and (un)fortunately, as an umbrella principle,it underpins a lot: so much that it is difficult to understand whether all aspects of negotiating chapter such as anti-corruption and fundamental rights in toto are to be considered as covered by the rule of law principle. If they are, it should be explicitly explained, as not to hinder the accession process with too wide or too narrow interpretation of the rule of law components, overstepping in the national competences. The political will of the countries involved on the one side, and the EU institutions on the other,as well as a substantially deeper involvement should be the two focus points. In addition, having in mind that the New Methodology is yet to be accepted by the two front runners in negotiations, Serbia and Montenegro, the EU has the chance to re-orient its focus, not only to the strong monitoring but also to the conceptualising what is the rule of law value that one country with differences in history, constitutional tradition, legal system which is going through the political, economic and legal transition, should adhere to or accept. And finally, the EU should pay attention to the creation of "perfect Member States" that will eventually throughout the "carrot and the stick" game, have a greater compliance with all the conditions, including values, than the existing Member States. 


\section{REFERENCES}

\section{BOOKS AND ARTICLES}

1. Baratta, R., Rule of Law 'Dialogues' Within the EU: A Legal Assessment, Hague Journal on the Rule of Law, no. 2, 2016, pp. 357-372

2. Claes, M., How Common are the Values of the European Union?, Croatian Yearbook of European Law and Policy, no. 1, 2019, VII-XVI

3. Drenovak-Ivanovic M.; Bogojevic S., Environmental Protection Through the Prism of Enlargement: Time for Reflection, Common Market Law Review, no. 56, 2019, pp. 949-978

4. Fisicaro, M., Rule of Law Conditionality in EU Funds: The Value of Money in the Crisis of European Values, European Papers, no. 3, 2019, pp. 695-722

5. Kochenov D.;Pech L., Better Late than Never? On the European Commission's Rule of Law Framework and its First Activation, Journal of Common Market Studies, no. 5, 2016, pp. 1062- 1074

6. Kochenov D., Elephants in the Room: The European Commission's 2019 Communication on the Rule of Law, Hague Journal on the Rule of Law, no. 11, 2019, pp. 423- 438

7. Kochenov D., The EU and the Rule of Law - Naïveté or a Grand Design?, in: Adams, M.et al. (eds.) Constitutionalism and the Rule of Law: Bridging Idealism and Realism, Cambridge, 2017, pp. 419-445

8. Herlin-Karnell E., The EU as a Promoter of Values and the European Global Project, 13 German Law Journal. no. 13, 2012, pp. 1225-1246

9. Hillion C., EU Enlargement, in:Craig, P.; Graine de Burca (eds.), The Evolution of EU law, Oxford University Press, 2011

10. Lenaerts K., New Horizons for the Rule of Law within the EU, German Law Journal, vol. 21, 2020, pp. 29-34

11. Lukić M., Pluralizam ustava ili ustavnih činilaca? Konstitucionalizacija prava Evropskeunije, Teme, no. 4, 2013, pp. 1705-1718

12. Oliver M., Enforcement of EU Values as a Political Endeavour: Constitutional Pluralism and Value Homogeneity in Times of Persistent Challenges to the Rule of Law, Hague Journal on the Rule of Law, 2019, pp. 133-170

13. Mineshima D., The Rule of Law and EU Expansion, Liverpool Law Review, no. 1-2, pp. 73-87

14. Pech L., A Union Founded on the Rule of Law: Meaning and Reality of the Rule of Law as a Constitutional Principle of EU Law, no. 6 Eu.Const, 2010, pp.359-396

15. Pejović A.A., Vladavina prava u politici prijema u Evropsku uniju, MaticaCrnogorska, no. 66, 2016

16. Pishev O., Dilemmas of the Transition Period, Problems of Communism, no.1-2, 1992, pp.66-68

17. Sadurski W., Adding Bite to a Bark: The Story of Article 7, EU Enlargement, and Jorg Haider, Colum. J. Eur. Law, no. 16, 2010, pp. 385-426

18. Tamanaha B., On the Rule of Law: History, Politics, Theory, Cambridge University Press, 2014 
19. Torcol S., Partager des valeurs communes, préalable à l'émergence d'un droit constitutionnel européen, Revue de l'Union européenne, 2017, pp. 389-395

20. Von Bogdandy A. et al., A potential constitutional moment for the European rule of Law - The importance of red lines, Guest Editorial, Common Market Law Review, vol. 55, pp. 983-996

21. Vlajkovic M.; Tasev J., The Lack of Uniform Understanding of the Rule of Law in the EU and its Implications on Prospective Member States, Transition of Legal Systems 30 Years after the Fall of the Berlin Wall, Law Review Iustinianus Primus Special Issue - Conference Proceedings, Skopje, North Macedonia

\section{COURT OF JUSTICE OF THE EUROPEAN UNION}

1. Case C-64/16, Associação Sindical dos Juízes Portugueses v Tribunal de Contas, Request for a preliminary ruling from the Supremo Tribunal Administrativo, ECLI:EU:C:2018:117

2. Case C-15/00 Commission v. BEI [2003], ECR I-7281

3. Case C-216/18 PPU Minister for Justice and Equality v LM, Judgment of the Court (Grand Chamber) of 25 July 2018 ECLI:EU:C:2018:586

4. Case C-229/05 P, Osman Ocalan, on behalf of the Kurdistan Workers' Party (PKK) and Serif Vanly, on behalf of the Kurdistan National Congress (KNK) v Council of the European Union, ECR [2007] i-349

5. Case C/294/83, Partié cologiste "Les Verts" v. European Parliament [1986] ECR 1986 $-01339$

6. Case C-50/00, Unión de Pequeños Agricultores v Council of the European Union [2002], ECR I- 667

7. Joined Cases C-585/18, C-624/18 and C-625/18 A.K. v Krajowa Rada Sądownictwa, and CP and DO v Sąd Najwyższy [2020] OJ C 27/6. Also see CJEU judgment: Case C-619/18 Commission v Poland (Independence of Supreme Court), ECLI:EU:C:2018:910

8. Joined Cases C-402/05 P and C-415/05, Yassin Abdullah Kadi and Al Barakaat International Foundation v Council of the European Union and Commission of the European Communities [2008] ECR I-6351

\section{EU LAW}

1. Council conclusions on Enlargement and Stabilisation and Association process 3132nd General Affairs Council meeting Brussels, 5 December 2011,

2. Commission, Decision of 13 December 2006 establishing a mechanism for cooperation and verification of progress in Romania to address specific benchmarks in the areas of judicial reform and the fight against corruption, OJ L 354, 14.12.2006, p. 58-60

3. Commission Proposal for a Regulation of the European Parliament and of the Council on the protection of the Union's budget in case of generalised deficiencies as regards the rule of law in the Member States, COM/2018/324 final - 2018/0136 (COD)

4. Copenhagen European Council, Presidency Conclusions [1993] SN 180/1/93 REV 1

5. Declaration on European Identity", Bulletin of the European Communities, Luxembourg: Office for official publications of the European Communities, No. 12, December 1973. 
6. The Treaty of Amsterdam amending the Treaty on European Union, the Treaties establishing the European Communities and certain related acts, Office for Official Publications of the European Communities, 1997.

7. Treaty establishing a Constitution for Europe, OJ C 310, 16.12.2004.

8. Treaty of Lisbon amending the Treaty on European Union and the Treaty establishing the European Community, Official Journal of the European Union C- 306, 2007

9. Treaty on European Union, Official Journal of the European Communities C 191/1, 1992

\section{LIST OF NATIONAL REGULATIONS, ACTS AND COURT DECISIONS}

1. House of Lords Select Committee on the Constitution, Relations between the executive, the judiciary and the Parliament, HL Paper 152, 2006-2007

\section{WEBSITE REFERENCES}

1. 2016 Communication on EU Enlargement Policy, [https://ec.europa.eu/neighbourhoodenlargement/sites/near/files/20161109_strategy_paper_en.pdf], accessed 20 March 2020

2. Argyropoulou Ventia, Enforcing the Rule of Law in the European Union, Quo Vadis $E U$ ?, [https://harvardhrj.com/2019/11/enforcing-the-rule-of-law-in-the-european-unionquo-vadis-eu/\#_ftn1], accessed 20 March 2020

3. Communication from the Commission (COM) 2014/0158 to the European Parliament and the Council a new EU Framework to strengthen the Rule of Law, 2014, [https://eurlex.europa.eu/legal content/EN/ALL/?uri=celex:52014DC0158], accessed 20 March 2020

4. Communication from the Commission to the European Parliament, the Council, the European Economic and Social Committee and the Committee of the Regions, A Credible Enlargement Perspective For and Enhanced EU Engagement With The Western Balkans, Strasbourg, 6.2.2018. the accession process - A credible EU perspective for the Western Balkans COM (2020) 57, [https://ec.europa.eu/neighbourhood enlargement/sites/near/files/ enlargement-methodology_en.pdf], accessed 20 March 2020

5. Delledone G., Homogeneity and Constitutional Diversity in the EU : Protecting Fundamental Rights and the Rule of Law, National University of Ireland Mayooth Keynote, [https://dial. uclouvain.be/pr/boreal/object/boreal:178155] accessed 22. February 2020

6. José Manuel Durão Barroso President of the European Commission State of the Union 2012 Address Plenary session of the European Parliament/Strasbourg 12 September 2012, [https://ec.europa.eu/commission/presscorner/detail/en/SPEECH_12_596], accessed 20. March 2020

7. Krajewski M., Associação Sindical dos Juizes Portugueses: The Court of Justice and Athena's Dilemma, [http://www.europeanpapers.eu/en/europeanforum/associacao-sindical-dos-juizesportugueses-court-of-justice-and-athena-dilemma], accessed 15. March 2020

8. Non-paper on the state of play regarding chapters 23 and 24 for Serbia, November 2019, [www.mei.gov.rs], accessed 20 March 2020

9. PM Orbán at Tusvanyos: "The essence of illiberal democracy is the protection of Christian liberty", [http://abouthungary.hu/blog/pm-orban-at-tusvanyos-the-essence-of-illiberal-democracy-is-the-protection-of-christian-liberty/], accessed 13 January 2020 
10. Speech: Safeguarding the rule of law and solving the "Copenhagen dilemma": Towards a new EUmechanism, [https://ec.europa.eu/commission/presscorner/detail/da/SPEECH_13_348], accessed 18. March 2020

11. The EU as a community of law: Overview of the role of law in the Union, [https://www.europarl. europa.eu/thinktank/fr/document.html?reference=EPRS_BRI\%282017\%29599364], accessed 10 March 2020

12. Venice Commission, Rule of Law Check-list[https:/www.venice.coe.int/webforms/documents/default.aspx?pdffile=CDL-AD(2016)007-e], accessed 17. March 2020 